International Journal of Current Advanced Research

ISSN: O: 2319-6475, ISSN: P: 2319 - 6505, Impact Factor: SJIF: 5.995

Available Online at www.journalijcar.org

Volume 6; Issue 3; March 2017; Page No. 2805-2807

DOI: http://dx.doi.org/10.24327/ijcar.2017.2807.0110

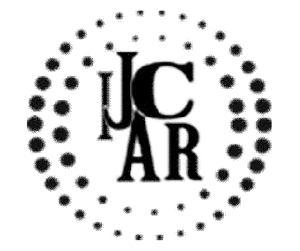

Research Article

\title{
EFFECT OF HERBAL TOOTHPASTE IN COMPARISON WITH TOOTHPASTE IN COMMERCIAL USE IN REDUCING STREPTOCOCCUS MUTANS COUNT
}

\section{P.S.Karthikeson and Geetha.R}

Department of Microbiology, Saveetha Dental College \& Hospitals, Chennai

\section{A R T I C L E I N F O}

\section{Article History:}

Received $18^{\text {th }}$ December, 2016

Received in revised form $16^{\text {th }}$ January, 2017

Accepted $26^{\text {th }}$ February, 2017

Published online $28^{\text {th }}$ March, 2017

\section{Key words:}

Herbal toothpaste, Commercial toothpaste, Bacterial count, Streptococcus mutans

\begin{abstract}
A B S T R A C T
Aim And Objective: To know about the effects of herbal toothpaste in comparison with tooth paste in commercial use in reducing streptococcus mutans count.

Background: Usage of toothpaste determines the shininess and colour of our tooth Commercial toothpaste contain fluoride, triclosan, propylene glycol, diethanolamine and artificial sweeteners. Commercially available herbal toothpastes are also there in market. The main ingredients of commercial herbal toothpastes include neem, pudina, tomar, laung etc. People use fluoridated toothpastes more than herbal toothpastes. But overuse of fluoridated toothpaste may lead to dental fluorosis. So in this study ,the herbal toothpastes, commercial toothpastes and commercially available herbal toothpastes are compared to get an idea about which toothpaste reduces bacterial count with less effect.
\end{abstract}

Methodology : A randomised study was carried out on 30 patients with dental caries. Saliva samples were collected prior to the procedure in a sterile container. The 30 patients were divided into three groups .10 subjects were given herbal tooth paste 1 and asked to brush twice a day morning and night before going to bed. Next 10 subjects were given Herbal tooth paste 2 and the rest 10 were given commercial tooth paste with fluoride and they were also instructed to follow the same procedure. After five days saliva samples were again collected from all the 30 subjects and Streptococcus mutans count was done and the results are given in Colony forming units $[\mathrm{cfu}] / \mathrm{ml}$. The mutans level is compared between three groups and compared.

Conclusion: Most of us don't use herbal toothpastes because it shows mild irritation in mouth. So people started to use fluoridated toothpaste since it doesn't show any irritation and it provides good breath. The bacterial count can be reduced if we use herbal toothpastes than commercial toothpastes. Also doctors should recommend herbal toothpastes here afterwards thus to provide good oral hygiene in near future.

Copyright $₫ 2017$ P.S.Karthikeson and Geetha.R. This is an open access article distributed under the Creative Commons Attribution License, which permits unrestricted use, distribution, and reproduction in any medium, provided the original work is properly cited.

\section{INTRODUCTION}

Everyone wants to have a great smile which is why good oral hygiene is important. Oral hygiene is the practice of keeping the mouth clean and healthy by brushing and flossing to prevent tooth decay and gum disease. The purpose of oral hygiene is to prevent the build up of plaque, the sticky film of bacteria and food that forms on the teeth. Plaque also irritates gums and can lead to gum disease (periodontal disease) and tooth loss. Having poor oral hygiene can lead to a variety of dental and medical problems ${ }^{[1],[2]}$. Plaques plays an important role in development of gingivitis when in contact with the gingival tissues and, therefore, plaque control represents the cornerstone of good oral hygiene practice. The tools most commonly used in mechanical supragingival plaque control

\section{*Corresponding author: P.S.Karthikeson}

Department of Microbiology, Saveetha Dental college \& Hospitals ,Chennai are the toothbrush (manual or electric), floss, woodsticks, and interdental brushes. Despite the availability of these various oral hygiene devices, even the most meticulous patient will not always completely remove all plaque. ${ }^{[3]}$ The removal of plaque is utmost important to control dental caries that is commonly maintained by mechanical methods. Usage of toothpaste determines the shininess and colour of our tooth. Commercial toothpaste contain fluoride, triclosan, propylene glycol, diethanolamine and artificial sweeteners. ${ }^{[4]}$

Herbal toothpaste is a unique formulation of natural ingredients that provide long lasting and complete oral care to gums and teeth .It contains herbal extract and essential oils that fights effectively against bacteria. The herbal paste not only cleans teeth but also bring freshness in breath ${ }^{[5],[6]}$. The use of herbal toothpaste is a good choice for everyone especially for them who are suffering from toothaches, bleeding gums and bad breathe. Various dental and gum disease can be cured easily with the use of herbal toothpaste. 
The herbal toothpaste are far better than harsh chemical laden synthetic toothpastes. Herbal toothpaste does not contain dyes or artificial flavourings. Herbal toothpaste lack artificial colours and flavours in its composition can be a great attraction. ${ }^{[7],[8]}$ The herbal-toothpastes contains mint, neem, basal, clove and many other herbs. Clove is rich in calcium and vitamin $\mathrm{C}$, provides relief from oral pain. Basil leaves acts as a disinfectant and kills the germs present in mouth. Mint, another special ingredient of the herbal-toothpastes not only controls the bad breath problem but also kills the harmful bacteria. Mint oils are actually the most effective ingredient to kill germs in the mouth. ${ }^{[9]}$ These ingredients fights regularly with the bacteria and protects teeth from further decaying. ${ }^{[10]}$

Neem is one of the best ingredients of herbal toothpaste. Neem toothpaste acts as a means incredible treatment to treat teeth and gum problems. Toothpastes are made of Neem bark and is really fantastic as a great healer of diseases of the gums and teeth and gingivitis.

Commercially available herbal toothpastes are also there in market. The main ingredients of commercial herbal toothpastes include neem, pudina, tomar, laung etc. People use fluoridated toothpastes more than herbal toothpastes. ${ }^{[11],[12]}$ But overuse of fluoridated toothpaste may lead to dental fluorosis. So in this study, the herbal toothpastes, commercial toothpastes and commercially available herbal toothpastes are compared to get an idea about which toothpaste reduces bacterial count with less effect.

\section{MATERIALS}

\section{Herbal toothpaste 1}

Active Ingredients: Laung, Tomar, Neem And Pudina

Herbal toothpaste 2

Active Ingredients: Acacia Arabica, Akarkara, Babool

Flouridated Toothpaste: Triclosan, Sodium Fluoride, Propylene Glycol

\section{METHODOLOGY}

A randomised study was carried out on 30 patients with dental caries. Saliva samples were collected prior to the procedure in a sterile container. The samples were sent to the microbiology lab to check for Streptococcus mutans level by culture method. The 30 patients were divided into three groups . 10 subjects were given herbal tooth paste 1 and asked to brush twice a day morning and night before going to bed. Next 10 subjects were given Herbal tooth paste 2 and the rest 10 were given commercial tooth paste with fluoride and they were also instructed to follow the same procedure. After five days saliva samples were again collected from all the 30 subjects and Streptococcus mutans count was done and the results are given in Colony forming units [cfu] / $\mathrm{ml}$. The mutans level is compared between three groups and tabulated in table 1 .

\section{RESULTS AND DISCUSSION}

The major strength of these natural herbs is that their use has not been reported with any side-effects till date. Natural herbs used either as whole single herb or in combination have been scientifically proven to be safe and effective medicine against various oral health problems like bleeding gums, halitosis, mouth ulcers and preventing tooth decay. In our present study we used two herbal tooth pastes. Composition of herbal toothpaste 1 includes Laung, tomar, neem and pudina. Composition of herbal toothpaste 2 includes Acacia Arabica, akarkara, babool etc. There was an significant reduction in the count of Streptococcus mutans with Herbal tooth paste 2 when compared with the fluoridated toothpaste, Followed by herbal toothpaste 2 , herbal toothpaste 1 also showed decrease in bacterial count. Even though fluoridated toothpaste reduces bacterial count, it is not much effective as herbal toothpaste.

\begin{tabular}{ccccccc}
\hline Days & $\begin{array}{c}\text { Herbal tooth } \\
\text { paste 1 }\end{array}$ & \multicolumn{2}{c}{$\begin{array}{c}\text { Herbal tooth } \\
\text { paste 2 }\end{array}$} & \multicolumn{2}{c}{$\begin{array}{c}\text { Fluoridated } \\
\text { toothpaste }\end{array}$} \\
\hline & Before & After & Before & After & Before & After \\
\hline 1 & 100 & 20 & 170 & 120 & 200 & 95 \\
2 & 95 & 40 & 35 & 10 & 450 & 280 \\
3 & 50 & 10 & 58 & 23 & 155 & 100 \\
4 & 500 & 290 & 30 & 9 & 190 & 150 \\
5 & 130 & 20 & 160 & 76 & 620 & 550 \\
6 & 200 & 109 & 150 & 40 & 250 & 200 \\
7 & 140 & 100 & 20 & 5 & 90 & 70 \\
8 & 75 & 28 & 210 & 70 & 320 & 150 \\
9 & 60 & 20 & 85 & 26 & 1200 & 700 \\
10 & 275 & 120 & 50 & 30 & 475 & 269 \\
\hline
\end{tabular}

\section{CONCLUSION}

Herbal toothpastes contain natural ingredients that gives long lasting and complete oral hygiene .It contains plant extracts that effectively fight against bacteria causing diseases.

Form the study we conducted it is evident that the herbal toothpastes reduced bacterial count compared with other commercially available toothpastes in market.

\section{References}

1. Barnes VM, Richter R, DeVizio W. Comparision of the short-term antiplaque/antibacterial efficacy of two commercial dentifrices. J Clin Dent. 2010; 21:101-4.

2. George J, Hegde S, Rajesh KS, Kumar A. The efficacy of a herbal-based toothpaste in the control of plaque and gingivitis: A clinic-biochemical study. Indian $J$ Dent Res. 2009; 20:480-2.

3. de Oliveira SM, Torres TC, Pereira SL, Mota OM, Carlos MX. Effect of dentifrice containing Aloe vera on plaque and gingivitis control. A double-blind clinical study in humans. $J$ Appl Oral Sci.2008;16: 293-6.

4. Radafshar G, Mahboob F, Kazemnejad E. A study to assess the plaque inhibitory action of herbal-based toothpaste: A double blind controlled clinical trial. $J$ Med Plants Res. 2010;4:1182-6.

5. Ozaki F, Pannuti CM, Imbronito AV, Pessotti W, Saraiva L, de Freitas NM, et al. Efficacy of a herbal tooth paste on patients with established gingivitis--a randamised controlled trial. Braz Oral Res. 2006;20:172-7.

6. Sushma S, Nandlal B, Srilatha KT. A comparative evaluation of a commercially available herbal and nonherbal dentifrice on dental plaque and gingivitis in children- A residential school based oral health programme. J Dent Oral Hyg. 2011;3:109-13.

7. Pannuti CM, Mattos JP, Ranoya PN, Jesus AM, Lotufo RF, Romito GA. Clinical effect of a herbal dentifrice 
on the control of plaque and gingivitis: A double-blind study. Pesqui Odontol Bras. 2003;17:314-8.

8. Mateu FA, Boneta AE, DeVizio W, Stewart B, Proskin HM. A clinical investigation of the efficacy of two dentifrices for controlling established supragingival plaque and gingivitis. J Clin Dent. 2008;19:85-94.

9. Mazumdar M, Chatterjee A, Majumdar S, Mahendra C, Patki PS. Evaluation of the safety and efficacy of complete care herbal toothpaste in controlling dental plaque, gingival bleeding and periodontal diseases. $J$ Homeop Ayurv Med. 2013;2:1-5.
10. Rubido S, Fernández-Feijoo J, Limeres J, GarcíaCaballero L, Abeleira MT, Diz P. In vivo antiplaque effect of three edible toothpastes. Med Oral Patol Oral Cir Bucal. 2014;19:e88-92.

11. Saxena S, Prashant GM, Chandu GN. Labaroterial evaluation of antimicrobial efficacy of herbal dentifrices commercialized in India. Arch Oral Res. 2011;7:51-60.

12. S.G Vishnu Prasanna, R. Abilasha, "In vitro comparison of antimicrobial efficacy of different toothpaste", Journal of Pharmaceutical Sciences and Research.

\section{Please cite this article in press as:}

P.S.Karthikeson and Geetha.R (2017), Effect Of Herbal Toothpaste In Comparison With Toothpaste In Commercial Use In Reducing Streptococcus Mutans Count, International Journal of Current Advanced Research, 6(3), pp. $2805-2807$. http://dx.doi.org/10.24327/ijcar.2017.2807.0110 